ISSN: 2224-0616

Int. J . Agril. Res. Innov. \& Tech. 4 (2): 16-21, December, 2014 Available online at http:// www.ijarit.webs.com

\title{
EFFECTS OF DIFFERENT KINDS OF FERTILIZERS ON PRODUCTION OF FISHES IN POLYCULTURE SYSTEM
}

\author{
M.J. Alam ${ }^{1,2}$, M. Shahjahan1*, M.S. Rahman1, H. Rashid1, M.A. Hosen ${ }^{1,2}$
}

Received 18 June 2014, Revised 4 November 2014, Accepted 22 December 2014, Published online 31 December 2014

\begin{abstract}
A study was conducted to assess the effects of different kinds of inorganic fertilizers on the production of fishes in six ponds during October to December 2011. There were three treatments with two replications under each treatment and each of the ponds was stocked with 80 fish fry. In treatments I, II and III, ponds were fertilized fortnightly @ urea $100 \mathrm{~g}$ decimal-1 , T.S.P. $100 \mathrm{~g} \mathrm{decimal}^{-1}$ and urea $50 \mathrm{~g} \mathrm{decimal}^{-1}+$ T.S.P. $50 \mathrm{~g} \mathrm{decimal}^{-1}$, respectively. Selected water-quality parameters of ponds under study were more or less similar and within the productive range. Mean phytoplankton and zooplankton densities under treatments I, II and III were 57.08 $\pm 1.35,8.80 \pm 0.09$ and $77.29 \pm 3.72,12.88 \pm 0.74$ and $98.93 \pm 1.61$, $16.16 \pm 1.75$ (x103) cells $\mathrm{L}^{-1}$, respectively. The net and gross fish productions of the ponds under treatments I, II and III were 0.85 and $3.11 \mathrm{t} \mathrm{ha}^{-1} \mathrm{yr}^{-1}$ and 1.32 and $3.58 \mathrm{t} \mathrm{ha}^{-1}$ $\mathrm{yr}^{-1}$ and 1.85 and $4.11 \mathrm{t} \mathrm{ha}^{-1} \mathrm{yr}^{-1}$, respectively. Fish production under treatment III was better than those under treatments I and II because plankton population densities under treatment III was the highest. Therefore, the mixed fertilization is suitable for production of plankton that enhance growth and production of fishes.
\end{abstract}

Keywords: Fish Culture, Pond, Limnological Factors, Fertilizer, Fish Production

${ }^{1}$ Department of Fisheries Management, Bangladesh Agricultural University, Mymensingh-2202, Bangladesh

${ }^{2}$ Department of Fisheries, Ministry of Fisheries and Livestock, Dhaka, B angladesh

*Corresponding author's email: mdshahjahan@bau.edu.bd (M. Shahjahan)

\section{Introduction}

Optimizing production in pond fish culture by the use of fertilizers is an important task. Fertilizer is helpful for the increase of natural food of fish i.e. plankton, benthos and periphyton. Plankton is the basic food of all the organisms living in the water. Fishes and other aquatic organisms depend on this basic food directly and indirectly. Extensive work on water quality and pond fertilization has been conducted elsewhere (Boyd, 1982) but very few of them have relevance to the Asian carp culture. Both over and under fertilization may cause adverse effects on fish production, water quality and economic returns. It is therefore necessary to evaluate fertilization regimes and recommend appropriate fertilization strategies to farmers in order to maximize fish production, maintain good water quality, reduce environmental bad impact and maximize economic returns.

Successful fisheries management and scientific fish culture depends on the various limnological factors of the water bodies. According to Hickling (1968) fish farming is a practical application of limnology and fresh-water biology, According to Reid (1971) the chemical analysis for dissolved gases and solids are highly important for the study of natural waters. He also reported that fish culture can be enhanced by the improvement of substratum by the use of fertilizers along with other pond management measures. The physicochemical characteristics of pond water are of great importance and essential in case of fish culture and fisheries management. The physicochemical properties play the most important role in governing the production of phytoplankton i.e. primary production in fishponds (Banerjee, 1967).

For successful aquaculture, knowledge on several factors is very important among which fertilization is one of them. The necessities and principles of fertilization of ponds for the increase of production are similar to those of crop production. The amount and proportions of various fertilizers needed vary from country to country and even from area to area within a country. The use of fertilizers in proper doses is also very important to reduce the unit cost of production. As for example, Hepher et al. (1971) found in Israel that if there applied no fertilizers in fishpond, the cost of production per ton was 935 dollars and after applying fertilizers, the cost of production of fish per ton was 691 dollars. Therefore, the present study was conducted to know the effects of different kinds of fertilizers on production of fishes in polyculture system along with some limnological parameters. 


\section{Materials and Methods}

The experiment was conducted for a period of three months from October to December 2011 in six experimental ponds at Bangladesh Agricultural University, Mymensingh, Bangladesh. The ponds were rectangular in size and similar in area (about $40 \mathrm{~m}^{2}$ ). They were numbered arbitrarily as $\mathrm{P}_{1}, \mathrm{P}_{2}, \mathrm{P}_{3}, \mathrm{P}_{4}, \mathrm{P}_{5}$ and $\mathrm{P}_{6}$ for the convenience of experimental work and data analysis. The ponds were treated by lime before two weeks of starting the experiment.

Table 1. Experimental layout

\begin{tabular}{llll}
\hline Treatments & Replication & Fish species \& ratio & Fertilization \\
\hline I & 2 (P1 \&P2) & Silver carp : tilapia : mrigal $(2: 2: 1)$ & Urea 100 g decimal $^{-1}$ \\
II & 2 (P3 \&P4) & Do & TSP 100 g decimal $^{-1}$ \\
III & 2 (P5 \&P6) & Do & Urea 50 g+TSP 50 g decimal-1 $^{-1}$ \\
\hline
\end{tabular}

\section{Stocking the pond}

The ponds were stocked with fingerlings of silver carp, tilapia and mrigal with the stocking density of $80(32+32+16)$ fingerlings per decimal. The average lengths of fingerlings of silver carp, tilapia and mrigal were $12.14 \mathrm{~cm}, 10.15 \mathrm{~cm}$ and $8.12 \mathrm{~cm}$, respectively.

\section{Fertilization}

Inorganic fertilizers such as only urea, only TSP and urea and TSP mixed were used for the experiment. Fertilizers were applied at fifteen days interval. In the ponds of treatment $1\left(\mathrm{~T}_{1}\right)$ only urea was applied at the rate of $100 \mathrm{~g}$ decimal $^{-1}$. In the ponds of treatment $2\left(\mathrm{~T}_{2}\right)$ only TSP was applied at the rate of $100 \mathrm{~g} \mathrm{decimal}^{-1}$. In the ponds of treatment III, urea and T.S.P. were applied at the rate of $50 \mathrm{~g}$ urea and $50 \mathrm{~g}$ TSP decimal $^{-1}$

\section{Study of physico-chemical factors}

The water samples were collected twice a month in the morning at about 10 a.m. The water samples were collected by dipping the bottle just below the surface water. All the bottles containing water samples were carried to the Laboratory of Limnology for analysis. The Physico-chemical factors which were studied are water temperature $\left({ }^{\circ} \mathrm{C}\right)$, water depth $(\mathrm{m})$, transparency $(\mathrm{cm})$, dissolved oxygen $\left(\mathrm{mg} \mathrm{L}^{-1}\right)$, Free $\mathrm{CO}_{2}\left(\mathrm{mg} \mathrm{L}^{-1}\right), \mathrm{P}^{\mathrm{H}}$ and total alkalinity ( $\mathrm{mg} \mathrm{L}^{-}$ 1). Water temperature was recorded with a Celsius thermometer and transparency was measured with a Secchi disc of $30 \mathrm{~cm}$ diameter. Dissolved oxygen was measured directly with a DO meter (Lutron, DO-5509) and a portable digital $\mathrm{pH}$ meter was used to measure $\mathrm{pH}$. Free
$\mathrm{CO}_{2}$ and total alkalinity were determined by titrimetric method (APHA, 1992).

\section{Study of plankton}

For the quantitative and qualitative study of phytoplankton and zooplankton of water, samples were collected from the different spots of water of the ponds with the help of bottle. Fifteen to thirty liters of water was passed through the plankton net (mesh size $55 \mu$ ) for each sample and the volume of sample collected was $30 \mathrm{ml}$. The concentrated samples were poured into vials and preserved by $5 \%$ formalin. Plankton samples were collected fortnightly. The study of plankton was done by a haemocytometer under a compound microscope and calculating by using following formula (Rahman, 1992):

$$
\mathrm{N}=\frac{\mathrm{A} \times 1000 \times \mathrm{C}}{\mathrm{V} \times \mathrm{F} \times \mathrm{L}}
$$

Where,

$\mathrm{N}=$ No. of plankton cells per $\mathrm{L}$,

$A=$ Total no. of plankton counted,

$\mathrm{C}=$ Volume of final concentrate of samples in $\mathrm{ml}$,

$\mathrm{V}=$ Volume of a field in cubic $\mathrm{mm}$,

$\mathrm{F}=$ Number of the fields counted,

$\mathrm{L}=$ Volume of original water in liter,

\section{Study of growth of fishes}

Before releasing the fingerlings in the ponds average initial length $(\mathrm{cm})$ and average weight $(\mathrm{g})$ were recorded with the help of a meter scale and a balance. At the end of the experiment all the fishes were caught by a cast net and then by using rotenone in the ponds. Fish mortality, gross and net productions have been calculated using the following formulas:

(i) The survival rate was estimated by the following formula

$$
\text { Survival rate }(\%)=\frac{\text { No. of harvested fishes }}{\text { Initial no. of fish }} \times 100
$$

(ii) Calculation of gross fish production $\left(\mathrm{t} \mathrm{ha}^{-1} \mathrm{yr}^{-1}\right)$

$$
=\frac{\text { Gross weight }(\mathrm{kg}) \text { of fish per decimal per month } \times 250 \times 12}{1000}
$$

(iii) Calculation of net fish production ( $\mathrm{tha}^{-1} \mathrm{yr}^{-1}$ )

$=\underline{\text { Net weight }(\mathrm{kg}) \text { of fish per decimal per month } \times 250 \times 12}$

$$
1000
$$




\section{Statistical analysis}

T-test of net fish production of the ponds under three treatments was done by a computer using SPSS package programme.

\section{Results}

\section{Physico-chemical parameters}

The results of physico-chemical parameters are shown in Table 2. All physical and chemical parameters of the ponds were found to be within the acceptable ranges for fish culture in all treatments.

Table 2. Physico-chemical parameters (Means $\pm \mathrm{SD} ; \mathrm{n}=3$ ) of the ponds during the experimental period

\begin{tabular}{lccc}
\hline Parameters & Treatment II & Treatment II & Treatment III \\
\hline Average water depth $(\mathrm{m})$ & $0.89 \pm 0.01$ & $0.85 \pm 0.04$ & $0.91 \pm 0.02$ \\
Water temperature $\left({ }^{\circ} \mathrm{C}\right)$ & $20.53 \pm 4.34$ & $20.53 \pm 4.34$ & $20.53 \pm 4.34$ \\
Transparency $(\mathrm{cm})$ & $35.41 \pm 2.89$ & $31.91 \pm 0.75$ & $31.35 \pm 1.71$ \\
$\mathrm{pH}$ & $7.38 \pm 0.20$ & $7.33 \pm 0.10$ & $7.48 \pm 0.37$ \\
Dissolved oxygen $\left(\mathrm{mg} \mathrm{L}^{-1}\right)$ & $9.50 \pm 0.58$ & $9.79 \pm 0.52$ & $10.12 \pm 0.36$ \\
Free $\mathrm{CO}_{2}\left(\mathrm{mg} \mathrm{L}^{-1}\right)$ & $1.21 \pm 0.16$ & $1.18 \pm 0.11$ & $1.22 \pm 0.12$ \\
Total alkalinity $\left(\mathrm{mg} \mathrm{L}^{-1}\right)$ & $106.08 \pm 5.02$ & $104.67 \pm 3.11$ & $112.17 \pm 5.56$ \\
\hline
\end{tabular}

\section{Plankton}

Mean phytoplankton and zooplankton densities under treatments I, II and III were $57.08 \pm 1.35$, $8.80 \pm 0.09$ and $77.29 \pm 3.72,12.88 \pm 0.74$ and $98.93 \pm 1.61,16.16 \pm 1.75\left(\mathrm{x} 10^{3}\right)$ cells $\mathrm{L}^{-1}$, respectively (Fig. 1 and 2). It was observed that both the phytoplankton and zooplankton densities were significantly higher in Treatment III. The generic status of phytoplankton and zooplankton found during the tenure of experiment are shown in Table 3. During the study period, 45 genera of phytoplankton belonging to five groups and 10 genera of zooplankton belonging to three groups were found in all the experimental ponds.

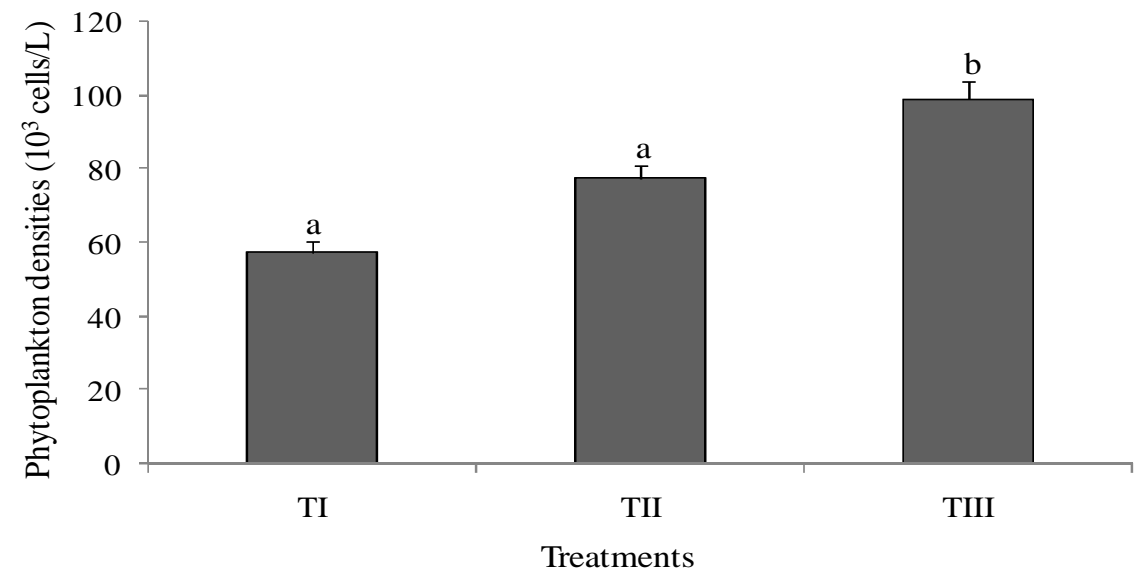

Fig. 1. Mean phytoplankton densities. Values accompanied by different letters are statistically significantly different $(\mathrm{p}<0.05)$.

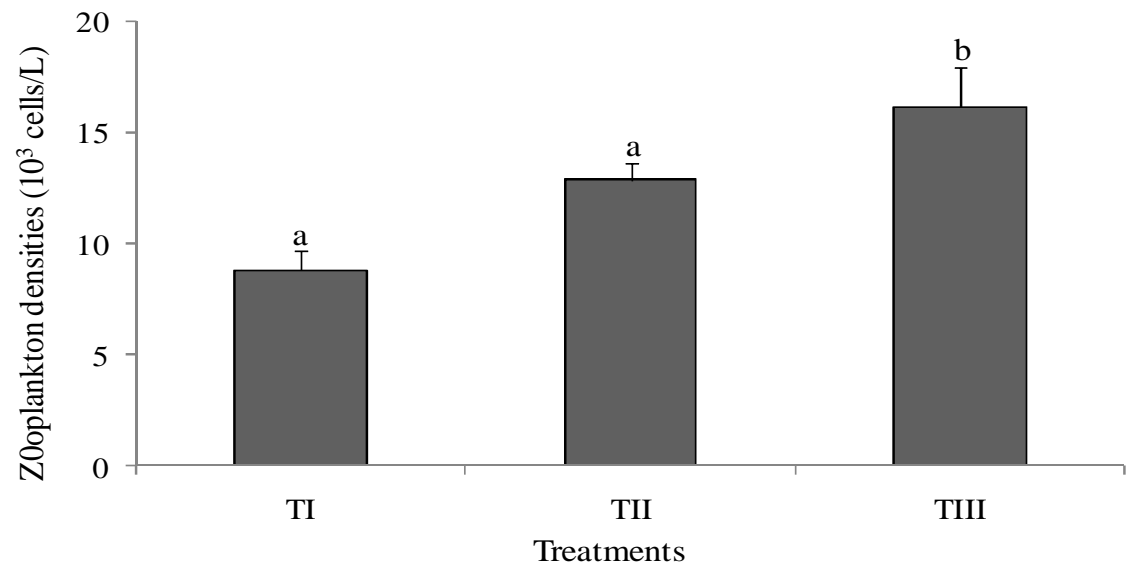

Fig. 2. Mean zooplankton densities. Values accompanied by different letters are statistically significantly different $(p<0.05)$. 
Table 3. Generic status of phytoplankton and zooplankton found in the experimental ponds

\begin{tabular}{|c|c|}
\hline Phytoplankton & Zooplankton \\
\hline $\begin{array}{l}\text { Bacillariophyceae: Navicula, Diatoma,,Cyclotella, } \\
\text { Melosira, Frustulia, Asterionella, Stauronesis, } \\
\text { Fragilaria, Synedra, Frustulia, Surirella } \\
\text { Chlorophyceae: Ulothrix, Ganatozygon, Gloeocystis, } \\
\text { Spirogyra, Euastrum,Chroococcus, Ophiocytium, } \\
\text { Protococcus, Volvox,Coelastrum, Cladophora, } \\
\text { Tetraedron,Histococcus, } \\
\text { Actinastrum,Closterium,Melosira, Scenedesmus, } \\
\text { Pediastru, Pediastrum, Ankistrodesmus, Selenastrum, } \\
\text { Actinastrum, Stistococcus } \\
\text { Cyanophyceae: Anabaena, Oscillatoria, Microcystis, } \\
\text { Nostoc, Spirulina, Aphanocapsa } \\
\text { Euglenophyceae: Euglena, Phacus, Trachelomonas }\end{array}$ & $\begin{array}{l}\text { Rotifera: Brachionus, Keratella, Filinia, } \\
\text { Polyarthra } \\
\text { Cladocera: Daphnia, Diaphanosoma, } \\
\text { Moina } \\
\text { Copepoda: Nauplius, Cyclops, Diaptomus }\end{array}$ \\
\hline
\end{tabular}

\section{Growth and production of fish}

The net productions ( $\mathrm{t} \mathrm{ha-1} \mathrm{yr}^{-1}$ ) of silver carp, tilapia and mrigal under three treatments have been presented in Fig. 3. The net productions of fishes are shown in Figure 4. Significantly highest net productions of fishes were obtained in Treatment III.

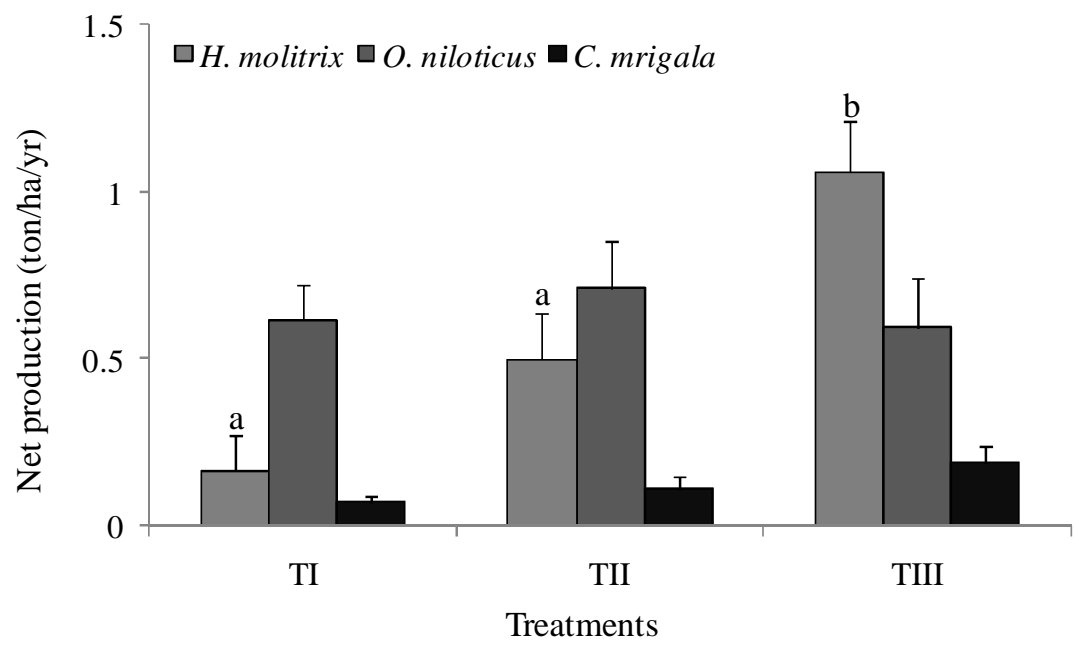

Fig. 3. Species wise net production of fish. Values accompanied by different letters are statistically significantly different $(\mathrm{p}<0.05)$.

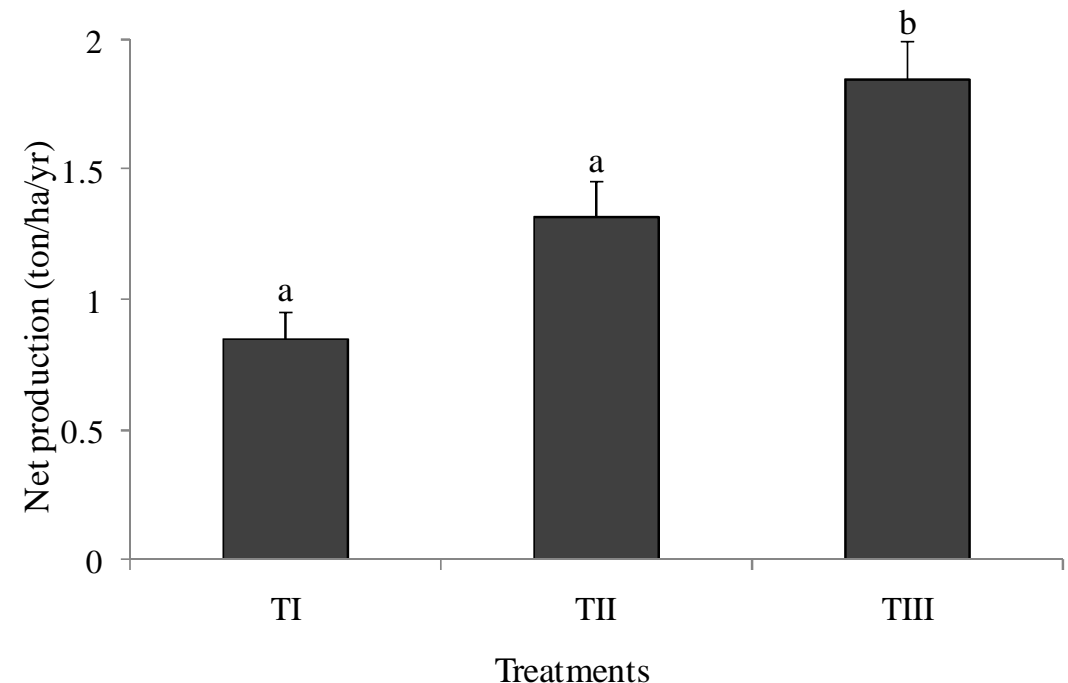

Fig. 4. Net production of fish. Values accompanied by different letters are statistically significantly different $(p<0.05)$. 


\section{Discussion}

The present study was conducted to evaluate the effects of fertilization on growth and production of fishes in polyculture of tilapia, silver carp and mrigal. The fishes showed better growth and production performance in supply of mixed fertilizer as both phytoplankton and zooplankton production were highest in this condition.

The physico-chemical parameters of the experimental ponds were within the productive ranges for the growth of plankton and benthos during the tenure of experiment (Table 2). Within limit productive ranges of such water quality parameters have also been observed by a number of authors (Uddin et al., 2007; Chowdhury et al., 2008; Uddin et al., 2012; Rahman et al., 2012; Talukdar et al., 2012; Siddika et al., 2012; Nupur et al., 2013) in the aquaculture ponds of BAU area which are in conformity with those of the present study.

In the present study, phytoplankton and zooplankton population densities were significantly higher in Treatment III (Figures 1 \& 2) indicating that both urea and TSP fertilizer needed for their production. More or less similar results also observed by Amin et al. (2005), Ferdousi et al. (2005), Uddin et al. (2007), Chowdhury et al. (2008) and Talukdar et al. (2012).

The net production of fishes of the ponds under treatment III was higher than those of treatments I and II. Higher net fish production of treatment III indicates the positive and better effects of mixed fertilization of urea and TSP on primary productivity as well as fish growth. All the species of fishes showed the highest rate of growth in all respects in treatment III, which is probably due to high production of both phytoplankton and zooplankton. More or less similar results recorded by Rabanal (1967). Saha et al. (1974) recorded that fertilizers enhanced growth of phytoplankton and zooplankton, which in turn induced better growth of fish. The yields of fish were higher in fertilized ponds compare to unfertilized ponds (Shahjahan et al., 2003). Donbrovskij et al. (1975) reported that introduction of mineral nitrogenous and phosphoric fertilizers increased the productivity of ponds by 1.4 times at the same stocking rate in fertilized ponds and by 2.3 times at higher stocking rates in fertilized ponds. Therefore, it can be concluded that the higher fish productions of treatment III was due to application of mixed fertilization of urea and TSP in the experimental ponds.

In conclusion, effects of fertilizer on the growth and production of fishes along with some limnological conditions were conducted in polyculture system under three treatments. In treatments I, II and III, ponds were fertilized fortnightly at the rates of urea $100 \mathrm{~g} \mathrm{decimal}^{-1}$, T.S.P. $100 \mathrm{~g} \mathrm{decimal}^{-1}$ and urea $50 \mathrm{~g} \mathrm{decimal}^{-1}+$ T.S.P. 50 g decimal- ${ }^{-1}$, respectively. Physicochemical parameters were more or less similar in the ponds under three treatments and were within suitable ranges. The net fish production of fish was significantly higher in Treatment III compared to Treatments I and II indicated that mixed fertilization might play a vital role in pond fish culture to increase production of fishes in polyculture system.

\section{References}

Amin, A.K.M.R., Bapary, M.A.J., Islam, M.S., Shahjahan, M. and Hossain, M.A.R. 2005. The Impacts of Compensatory Growth on Food Intake, Growth rate and Efficiency of Feed Utilization in Thai Pangas. Pakistan J. Biol. Sci. 8: 766-770.

APHA. 1992. Standard Methods for the Examination of Water and Wastewater. American Public Health Association, Washington DC. p. 874.

Banerjee, S.M. 1967. Water quality and soil condition of fish ponds in some states of India in relation to fish production. Indian J. Fish. 14: 115-144.

Boyd, C.E. 1982. Water Quality Management For Pond Fish Culture.Elsevier Science Publishers B.V., 1000 AH Amsterdam, The Netherlands. 318p.

Chowdhury, M.M.R., Shahjahan, M., Rahman, M.S. and Sadiqul Islam, M. 2008. Duckweed (Lemna minor) as supplementary feed in monoculture of nile tilapia, Oreochromis niloticus. J. Fish \& Aqu. Sci. 3: 54-59.

Donbrovskij, V.K., Lyakhnovich, V.P., Evodokimova, L.V. and Levchekova, N.I. 1975. Effects of mineral fertilizer and stoking rate on the fish proctivity of ponds and on the growth, feeding and energy balance of carps. Tr. Beintirkh, 10: 208.

Ferdoushi, Z., Shahjahan, M. and Haque, F. 2005. Impacts of different aquatic macrophytes (duckweed) on the growth and production of different fish. Prog. Agric. 16: 149-155.

Hepher, B., Chervinski, T. and Tagari, H. 1971. Studies on carp and silver carp nutrition III. Experiments on the effect on fish of dietary protein source and concentration. Bamidgeh, 23 (1): 11-37.

Hickling, C.F. 1968. The Farming of Fish, 1st ed., Pergamon Press Ltd., Oxford, 88p.

Nupur, N., Shahjahan, M., Rahman, M.S. and Fatema, M.K. 2013. Abundance of macrozoobenthos in relation to bottom soil 
textural types and water depth in aquaculture ponds. Int. J. Agril. Res. Innov. \&Tech. 3 (2): 1-6.

Rabanal, H.R. 1967. Inorganic fertilizer for pond fish culture. FAO Fish. Rep. 44: 164-173.

Rahman, M.S. 1992. Water Quality Management in Aquaculture. BRAC Prokashana, Mohakhali, Dhaka, Bangladesh, 84p.

Rahman, M.S., Shahjahan, M., Haque, M.M. and Khan, S. 2012. Control of euglenophyte bloom and fish production enhancement using duckweed and lime. Iranian J. Fish. Sci. 11: 358-371.

Reid, G.K. 1971. Ecology of Inland Waters and Estuaries. Reinhold Publishing Corporation, New York, Amsterdam. 767p.

Saha, G.N., Chatterjee, D.K. and Raman, K. 1974. Observations on manuring nursery ponds with only chemical nitrogenous fertilizers for successful rearing of carp spawn. J. Inland fish. Soc. India, 6: 162-166.

Shahjahan, M., Islam, M.S., Bapary, M.A.J. and Miah M.I. 2003. Socioeconomic conditions of fisherman of the jamuna River. Bangladesh J. Fish. 26: 47-52.

Siddika, F., Shahjahan, M. and Rahman, M.S. 2012. Abundance of plankton population densities in relation to bottom soil textural types in aquaculture ponds. Int. J. Agril. Res. Innov. \& Tech. 2 (1): 56-61.

Talukdar, M.Z.H., Shahjahan, M. and Rahman, M.S. 2012. Suitability of duckweed (Lemna minor) as feed for fish in polyculture system. Int. J. Agril. Res. Innov. \& Tech. 2 (1): $42-46$.

Uddin, M.N., Rahman, M.S. and Shahjahan, M. 2007. Effects of duckweed (Lemna minor) as supplementary feed on monoculture of GIFT strain of tilapia (Oreochromis niloticus). Prog. Agric. 18: 183-188.

Uddin, M.N., Shahjahan, M. and Haque, M.M. 2012. Manipulation of species composition in small scale carp polyculture to enhance fish production. Bangladesh J. Prog. Sci. \& Tech. 10: 9-12. 